\title{
Trade liberalisation and economic geography in CEE countries: the role of FDI in the adjustment pattern of regional wages
}

Joze P. Damijan \& Crt Kostevc

To cite this article: Joze P. Damijan \& Crt Kostevc (2011) Trade liberalisation and economic geography in CEE countries: the role of FDI in the adjustment pattern of regional wages, PostCommunist Economies, 23:02, 163-189, DOI: 10.1080/14631377.2011.570041

To link to this article: http://dx.doi.org/10.1080/14631377.2011.570041

Published online: 16 May 2011.

Submit your article to this journal $\pi$

ఋ Article views: 129

Q View related articles $\square$

Citing articles: 4 View citing articles $\sqsubset$ 


\title{
Trade liberalisation and economic geography in CEE countries: the role of FDI in the adjustment pattern of regional wages
}

\author{
Joze P. Damijan ${ }^{\mathrm{a}, \mathrm{b}}$ and Crt Kostevc ${ }^{\mathrm{a} *}$ \\ ${ }^{a}$ University of Ljubljana, Slovenia; ${ }^{b}$ LICOS, KU Leuven
}

(Received 26 November 2010; final version received 24 January 2011)

\begin{abstract}
This article studies the within-country regional effects of trade liberalisation in Central and Eastern European countries. CEE countries liberalised their trade with the European Union from the mid-1990s, while also receiving substantial foreign investment in the process. The first part of the period witnessed strong agglomeration effects in all of the countries, leading progressively to core-periphery type specialisation, and increasing regional wage differentials. In the second part of the period, however, there is notable evidence of a reversal in the relative regional specialisation, pointing to a U-shaped pattern of relative regional wages. Using the regional data for five CEE countries in 1990-2004 we argue that FDI inflows can be an important factor accelerating the observed regional adjustment process in the host country. First, we show that in four out of five CEE countries there is a significant U-shaped adjustment pattern of regional wages after they opened up to foreign trade. Second, we find robust econometric confirmation that in three of the five countries FDI has contributed significantly to faster adjustment of relative regional wages.
\end{abstract}

The opening-up of former socialist countries of Central and Eastern Europe (CEECs) and their trade integration with the European Union (EU) resulted in an extensive restructuring of production. While the vast majority of studies on economic restructuring in CEECs so far have dealt with inter-sectoral restructuring of production, this article focuses on interregional relocation of production within individual countries. The transition from a closed economy to complete trade liberalisation with the EU brings us as close to a large-scale natural experiment for assessing the relevance of the new economic geography (NEG) models as we are likely to get. Despite scepticism about the simplifying assumptions and 'overly' specific functional forms expressed by Neary (2001) in an excellent overview of the field, NEG models enable us to analyse the effects of trade liberalisation on international as well as intra-national relocation of manufacturing activity. The exact pattern of relocation of manufacturing activity, however, is ambiguous and dependent on the underlying assumptions. Crucially, assumptions about inter-regional factor mobility as well as the approach to the formalisation of agglomeration/dispersion forces determine the model's predictions and implications. These can be surprisingly diverse, ranging from increasing (or complete) agglomeration as in Krugman (1991a, 1991b) and Puga and Venables (1997) to a more even spread of economic activity (Krugman and Venables 1995, Puga 1999).

*Corresponding author. Email: crt.kostevc@ef.uni-lj.si 
So far only a few authors (Brülhart et al. 2004, Crozet and Koenig 2004, Egger et al. 2005, Brülhart and Koenig 2006) have studied the effects of trade liberalisation on the inter-regional relocation of production in CEECs. It is interesting, however, that while most of the empirical studies demonstrated that inter-sectoral restructuring in CEECs has been associated with massive inflows of foreign direct investment (Damijan and Rojec 2007), the impact of FDI on inter-regional relocation of production and wage disparities has been widely neglected. The novelty of our approach compared with the abovementioned studies on CEECs is that it focuses on explaining the dynamics of regional adjustment in response to trade liberalisation. Also, using longer time series on CEE countries allows us to study the relocation process in greater detail as the adjustment may take longer to unravel. Finally, our contribution also lies in the introduction of international capital flows as a (possibly crucial) factor in regional development in transition economies.

The primary contribution of the article hence lies in the empirical analysis of the effects of trade liberalisation with the EU on inter-regional relocation of manufacturing and inter-regional adjustment of relative wages in CEE countries. We focus on the exact adjustment pattern of relative regional wages, examining how NEG models, extended to take account of international and interregional capital mobility, can explain the actual regional adjustment pattern in selected CEE countries. Specifically, we study whether the response of relative regional wages to a reduction of foreign trade costs is monotonic and leads to strong regional polarisation as first suggested by Krugman (1991b) or is nonmonotonic and associated with less pronounced regional polarisation as suggested by more recent NEG approaches. In addition, in the case of a non-monotonic response we test whether the regional pattern of FDI inflows can explain the regional adjustment pattern of wages. Implications of NEG models are tested using a unique regional data panel for five CEE countries (Bulgaria, Estonia, Hungary, Romania and Slovenia) in 1990-2004.

Our results suggest that the expected U-shaped adjustment pattern of relative wages is confirmed by the data in four of the five countries analysed. In addition, after careful examination and using the appropriate panel data techniques as well as controlling for the potential endogeneity between wages and FDI, we find that in three of the five countries FDI is shown to have the theoretically suggested effect. FDI contributes to faster adjustment of relative regional wages in regions more heavily affected by trade liberalisation. Based on these findings one can argue that, owing to the inherent imperfect inter-regional mobility of labour, foreign direct investment can be an important factor helping to mitigate the potentially negative effects of trade liberalisation in peripheral regions.

The structure of the article is as follows. First we review previous empirical studies. Next we describe the empirical model and then we discuss the datasets used and descriptive statistics of the crucial variables in our empirical model. The following section discusses econometric methodology issues and presents estimation results both for the static and for the dynamic specification of the model. The final section summarises the basic findings of the study and provides some policy implications.

\section{Previous empirical studies}

Pioneering efforts in empirical research on the new economic geography's implications were made by Hanson $(1996,1997)$ with the analysis of the effects of Mexican trade liberalisation on the country's internal economic geography. From a closed economy 
setting, where manufacturing was concentrated near the capital city, trade liberalisation caused manufacturing to relocate towards the Mexico-US border. This, as Hanson shows, leads to a convergence in relative regional wages and an increase in border-region employment. In another of the earlier empirical papers on the NEG implications of trade liberalisation, Brülhart and Torstensson (1996) propose a non-monotonic relationship between regional integration and geographical concentration of increasing-returns industries in EU countries. They find mixed evidence, however, and prove this hypothesis only indirectly by finding some support for it solely in intra-industry trade flows among EU countries. Forslid et al. (2002) use a large-scale CGE model to simulate the effects of economic integration on the location of industrial production. They discover a nonmonotonic relationship between trade liberalisation and concentration of production (inverted U-shape) for industries driven by economies of scale, while a monotonic relationship is observed for comparative advantage-driven industries. Brakman et al. (2004) estimate the Helpman-Hanson empirical model (compare Helpman 1998, Hanson 2005) using data for Germany. An advantage of the Helpman-Hanson model is that it incorporates the fact that agglomeration of economic activity increases the prices of local (non-tradable) services. Using specific data for 151 districts for 1994 the authors succeeded in supporting the idea of a spatial nominal wage structure in Germany. Similarly, Mion (2004) extends the Helpman model to include multiple locations and tests its implications on data for Italian provinces. Following a variant of Hanson's empirical strategy, he shows that final demand linkages influence the distribution of earnings and, in contrast to Hanson's findings, that the scope for such spatial externalities need not be limited.

Recently, research on the implications of NEG models for patterns of economic activity in CEE countries too has been undertaken. Important work on studying the regional relocation processes in CEE countries has been done by a number of researchers who present their findings in a monograph edited by Traistaru et al. (2003). They find that increasing economic integration of CEE countries with the EU during the 1990s resulted in significant inter-regional relocation of manufacturing activity in selected countries. The winners in this process are either capital regions or western and northern regions that are bordering (or closer to) the large EU markets. In a related study by Crozet and Koenig (2004) data on Romanian regions for 1991-97 are used and the authors find that, in line with theoretical predictions, trade liberalisation favours the economic development of border regions when the positive effects are not outweighed by competitive pressure from the international markets. ${ }^{1}$ Brülhart and Koenig (2006) analyse the internal spatial wage and employment structures in five Central European transition economies between 1996 and 2000. They show that although wages and location of economic activity comply with NEG predictions, wages are discretely higher in capital regions where service employment is strongly concentrated. The observed concentration of economic activity in capital regions (termed 'the Comecon hypothesis') is significantly stronger than in EU member states. On the other hand, Egger et al. (2005) study $\sigma$-divergence of regional wages in eight CEECs. Using data on broad, NUTS-2 regions for the period 1991-98 they find significant convergence of real wages only in Poland and Bulgaria. However, they establish that countries with faster growing export openness experienced larger increases in their regional disparities, lending support to the notion that trade liberalisation leads to an initial divergence in regional economic concentration and regional wages. ${ }^{2}$ 


\section{The empirical model}

The majority of the standard NEG models do not deliver very clear predictions. Most of the models (such as Krugman (1991b) and Krugman and Venables (1995)) are suited to the case of two countries only (large vs. small country analysis). At the same time, the predictions of these models are not uniform and are subject to multiple equilibria depending on parameter values. In addition, these predictions change substantially with modifications in model assumptions and spatial framework. ${ }^{3}$ The implications of twocountry models therefore, depending on the assumptions used (factor mobility, intermediate goods etc.), range from complete agglomeration to perfect dispersion of economic activity. While Krugman and Livas Elizondo (1996) in a two-country threeregion framework predict that a decrease in international transport cost between the countries may foster a monotonic dispersion of economic activity in the smaller country, Alonso-Villar (2001) in a three-country framework, Monfort and Nicolini (2000) in a twocountry four-region framework and Paluzie (2001) in a two-country three-region framework argue that trade liberalisation is more likely to foster agglomeration of economic activity in a country opening to trade. Finally, Crozet and Koenig (2004) show in a two-country three-region framework that trade liberalisation is likely to favour the development of border regions.

Compared with the above NEG models and based on a version of an asymmetriclocation NEG model with mobile capital (Damijan and Kostevc 2008), we generate a set of clear and unique predictions for the effects of trade liberalisation on reallocation of economic activity. These predictions are based on the outcomes of a model with three asymmetrically placed regions (with the smaller home-country region enjoying a proximity advantage to the larger foreign country), imperfectly mobile labour and internationally mobile capital. A foreign investor considering the smaller country is faced with the choice of two locations, where advantages of agglomeration, infrastructure, relative wages and investor incentives will be among the many factors impacting the ultimate location decision (Jones and Wren 2006, Braunerhjelm and Thulin 2009). Crucially, all of the countries considered in this study employ or have employed investment incentives that specifically target less developed regions (Rojec et al. 2010). While lower relative wages, proximity to the EU markets and location-specific investment incentives certainly benefit border regions compared with economic centres in terms of attracting investment, agglomeration effects improve the attractiveness of the central location. Ultimately, the spatial pattern of international capital flows is determined by the relative strength of these opposing forces.

The effects of trade liberalisation in such a setting are potentially dual. Mobile factors of production will tend to foster agglomeration, which, in turn, is also selfreinforcing. The asymmetric positioning of the two home-country regions vis-à-vis the larger foreign country counteracts these agglomeration tendencies to a certain extent as proximity to the foreign market affords the smaller domestic regions greater benefits from trade liberalisation. In non-border regions this adjustment pattern, although present, might be less pronounced owing to diminished initial market access. The direction and speed of the adjustment of economic activity across the regions will hence depend on the relative strength of these opposing forces. Given that low intra-country labour mobility is well documented for CEE countries, ${ }^{4}$ we can assume that the adjustment pattern of relative regional wages is likely to be non-linear along the lines of Krugman and Venables (1995, 1996) and Krugman and Livas-Elizondo (1996) as opposed to models with a highly mobile labour force (Krugman 1991a, 1991b). Foreign investment, as 
noted above, could serve as either a dispersion or an agglomeration force depending on its destination within the host country. Furthermore, the effect could well depend on the progress of the liberalisation process as well, where the relationship between a reduction in trade costs and shifts in the concentration of economic activity tends not to be linear. A common feature of NEG models with low factor mobility and symmetrically positioned regions is that initial agglomeration forces tend to prevail, promoting further divergence but only at a lower level of trade costs.

In order to estimate the impact of FDI on the spatial reallocation of economic activity after and during trade liberalisation, we propose the following testable empirical model based on the above discussion and theoretical considerations. We measure relative economic activity with relative regional wages $\left(w_{2} / w_{1}\right)$ because this is clearly the measure of choice in most NEG models and also because it indicates the ultimate outcome of relative regional performance. Given that we are interested in measuring the convergence/divergence relative to the relevant economic frontier, we measure wages of all regions relative to that of the country's most developed region (i.e. economic centre). In order to try and control for the relative scope for external economies of scale in both regions (i.e. agglomeration effects), we introduce relative size of the regions (again, relative to the economic centre) in terms of the number of firms. The relative importance of regional foreign direct investment is, similarly, measured by the number of foreignowned firms in a region, relative to the central region. Finally, further control variables are employed to net out temporal effects, region-specific effects and other indicator variables.

Based on this we can specify our empirical model as:

$$
r W=f(r n, \text { time, FTA, BORD) }
$$

where $r W\left(=w_{2} / w_{1}\right)$ denotes relative regional wages and $r n\left(=n_{2} / n_{1}\right)$ is relative number of firms in region 2 relative to the capital region. We decompose relative number of firms further into domestic-owned $r n^{D}\left(=n_{2}^{D} / n_{1}^{D}\right)$ and foreign-owned firms $r n^{F}(=$ $F_{(}\left(=n_{2}^{F} / n_{1}^{F}\right)$. Hence, by construction, $r n^{F}$ indicates relative importance of FDI in region $r$ relative to the capital region. Given that the vast majority of firms in a given region are domestically owned, the relative regional size is proxied by the relative number of domestically owned firms. The relative regional size also reflects the wider array of agglomeration forces which impact broader spatial distribution of economic activity. As capital mobility is assumed to be greater than mobility of labour, we believe that, rather than region-specific, interest rates are firm-specific. As is the case with other unobserved firm characteristics, we employ the fixed-effects estimator to account for these variables. For transport/trade cost, we would ideally have time series data on transport cost between regions and with foreign countries as well as time series data on tariffs and other trade barriers for each individual region in the selected countries. However, as no such time-variant indicator of transport/trade cost at the regional level in selected CEE countries is available, we try to account for the dynamics of transport/trade cost by including three different variables. We include time, which is a time trend, to account for time-related decreasing dynamics of overall transport cost. ${ }^{5}$ In addition, we include FTA, a dummy variable for enforcement of a free trade agreement between an individual country and the European Union (EU). FTA accounts for speeding up of trade liberalisation after the enforcement of FTAs. Finally, BORD captures border region specific dynamics of trade liberalisation.

Based on the above implications of our model, we examine the spatial repercussions of trade liberalisation in $\mathrm{CEE}$ countries and explain the factors driving the adjustment pattern 
of regional wages by estimating the following empirical model:

$$
r W_{i t}=\alpha+\nu t+\omega t^{2}+r n_{i t}+\varphi r F D I_{i t}+\gamma B O R D_{i}+\lambda F T A+\varepsilon_{i t}
$$

where:

$r W_{i t}$ relative regional wage (i.e. wage ratio of region $i$ to the capital region)

$t, t^{2}$ time effects (i.e. linear and squared time trend)

$r n$ relative size of a region calculated as the relative number of domestically owned firms in region $i$ relative to the capital region

$r F D I_{i t}$ relative regional FDI calculated as the ratio of the number of foreign-owned firms to the total number of firms in region $i$ relative to the capital region

$B O R D_{i}$ dummy for western/northern border regions

FTA dummy for enforcement of trade liberalisation with the EU

$\varepsilon_{i t}$ iid. error term.

Note that in all of the subsequent analyses and empirical estimations we use relative regional indicators in order to capture inter-regional relocation patterns in a particular transition country. Relative regional indicators for wages and FDI are thus calculated as the ratio of the $r$-th region's performance to the capital (c) region's performance.

Based on the above discussion and the expected fit of NEG models to the actual data on CEE economies, we expect the following pattern of coefficients in our empirical model. Initially, trade liberalisation as proposed in models with limited or no labour mobility should cause a divergence of relative regional wages but, depending on the length of the period of observation and the strength of dispersion forces, this divergence might be overcome after a certain time period. We therefore expect either a significantly negative or non-significant coefficient of the FTA variable, depending on the length of the datasets. Second, regional data for CEE countries should exhibit a U-shaped curve of relative regional wages. We therefore expect a significant negative sign of the trend variable $t$ and a significant positive sign of the squared trend variable $t^{2}$. Third, the regional pattern of FDI inflows should have a significant impact on the above adjustment pattern of relative regional wages. Depending on whether investors choose to target the existing economic centres or focus on the developing periphery the sign of the coefficient on the $r F D I_{i t}$ variable will be either negative or positive. ${ }^{6}$ Fourth, after the initial divergence $W / N$ border regions should exhibit faster convergence and higher levels of relative wages compared with non-border regions, given their preferential location and the potential for investment inflows. We therefore expect a significant positive coefficient on the border variable $B O R D_{i}$.

The methodological issues related to estimation of Equation (2) as well as the estimation approaches used are discussed in the section presenting the results. Before presenting and discussing the results we discuss the data and descriptive statistics of the crucial variables in the empirical model.

\section{Data and descriptive statistics}

\section{Data}

We analyse the above propositions using regional data for five CEE countries that became EU members in 2004 and 2007. These countries are Bulgaria, Estonia, Hungary, Romania and Slovenia. The choice of countries is not completely arbitrary; it is simply subject to the 
Table 1. Coverage of regional data by countries.

\begin{tabular}{lrrrrr}
\hline & Bulgaria & Estonia & Hungary & Romania & Slovenia \\
\hline Data coverage & $1990-99$ & $1992-99$ & $1990-99$ & $1992-99$ & $1994-00$ \\
FTA in force & 1994 & 1994 & 1992 & 1993 & 1997 \\
Number of NUTS-2 regions $^{\mathrm{a}}$ & 6 & 5 & 7 & 8 & 12 \\
Number of NUTS-3 regions $^{\mathrm{b}}$ & 28 & 15 & 20 & 41 & 166 \\
\hline
\end{tabular}

Notes: ${ }^{\text {a }}$ NUTS-3 regions in Slovenia. ${ }^{\mathrm{b}}$ NUTS-5 regions in Slovenia.

availability and quality of the data. The countries examined in our study are very heterogeneous both in terms of their level of development and advancement of the transition process and in terms of their distance to the core of the EU. One may thus expect that the border effects in more distant countries like Bulgaria and Romania, which are also less advanced, will be less pronounced than in the EU-bordering CEE countries like Hungary and Slovenia ${ }^{7}$.

The data used in this study were collected during two research projects on the regional pattern of production relocation in CEE countries. ${ }^{8}$ The data for all countries were collected at both NUTS-2 and NUTS-3 levels which, compared with other regional studies on CEE countries, allows a more precise analysis of the spatial repercussions of trade liberalisation in these countries. ${ }^{9}$

Table 1 gives more information on our datasets, such as the number of regions and time of enforcement of trade liberalisation with the EU (FTA). We make use of long panels of regional data at the NUTS-3 level with data starting in the early 1990s and ending as recently as possible. Owing to different data availability the periods covered by the datasets for individual countries do not overlap completely. For Bulgaria and Hungary our datasets cover 1990-99, for Romania our dataset covers 1992-99, while for Estonia and Slovenia our datasets cover 1992-2004 and 1994-2003 respectively. The number of NUTS-3 regions, which serve as our units of observation, ranges between 12 (Slovenia) and 41 (Romania). Wage data are recalculated into 1994 constant prices using PPI indices. We use data for the manufacturing sector only, as other sectors are far less subject to trade liberalisation.

In the empirical estimations, regional data at the more disaggregated NUTS-3 level are taken for individual observations. While wage data and data on FDI do not require further explanation, some clarifications should be made with regard to the trade liberalisation variable FTA. Unfortunately, with the exception of Slovenia, we lack data on the evolution of actual foreign trade barriers over the period under examination at both the country and the regional level. Ideally, one should take the time pattern of actual foreign trade barriers (tariffs, NTBs) at the regional level and estimate the impact of their reduction on spatial repercussions in each country, but as no such data are available, we must rely on data on the date when the free trade agreement (FTA) with the EU came into force. This, however, poses several problems. First, in some of the countries a FTA came into force at the beginning of the period under examination, which of course eliminates the reference period needed for comparison of the economic geography effects before and after trade liberalisation. Second, some of the countries examined (Slovenia) unilaterally liberalised their trade even before the FTA came into force. Third, FTAs with the EU were designed asymmetrically in favour of CEE countries. Hence, the date the FTA came into force does not imply that trade barriers were reduced linearly from that point on. In all of the countries, trade barriers for the most sensitive goods were eliminated at the end of the 
period examined. However, there is little one can do about this problem. What remains is to be cautious when discussing the results. On the other hand, we have separately estimated the model with Slovenian data using either the FTA dummy variable or the data on actual tariffs applied by regions. The two estimations, however, do not differ significantly in terms of the signs and significance of the parameters for trade liberalisation.

\section{Evolution of relative regional wages}

In this section we examine the evolution of relative regional wages by individual countries. The graphic analysis depicted in Figure 1 combined with some descriptive statistics in Table A1 (in the Appendix) give us a clear insight into the pattern of relative wages after countries liberalised trade with the EU. Figure 1 reveals that all the countries, with the exception of Bulgaria, already experienced significant dispersion of regional wages before trade liberalisation started. In the early 1990s the standard deviation of regional wages in all the countries was between 0.08 and 0.10 (i.e. between $9 \%$ and $15 \%$ when measured with the coefficient of variation) with the exception of Bulgaria where it was below $5 \%$. On the other hand, in the early 1990s the average relative regional wage (measured by the mean or median) compared with the central region was quite high in Bulgaria, Romania and Slovenia (92, 95 and 87\% respectively), but lower in Hungary (82\%) and Estonia, where it was only about $67 \%$ of that in the central region.

In line with the predictions of our model, most of the countries' relative regional wages declined in the course of trade liberalisation. In Bulgaria, Hungary and Romania the decline in the average relative regional wages until 1999 was very large-by $14-15 \%$ relative to the central region. Only in Estonia and Slovenia did relative regional wages increase over the period-by $1 \%$ in Slovenia and 5\% in Estonia. One has to bear in mind, however, that for Slovenia and Estonia we can track changes in regional wages until 2003 and 2004 respectively, while for the other three countries we can only observe the pattern of regional wages until 1999. This may be very important since-as revealed by Figures 2 and $3 a-$ the evolution of relative regional wages in all of the countries examined seems to follow a U-shaped adjustment pattern. One can therefore expect that relative wages in Bulgaria, Hungary and Romania would have recovered after 1999, when our datasets end. Indeed, in Bulgaria and Romania, the lowest point in divergence of regional wages was reached in 1996, in Hungary in 1998 and in Estonia and Slovenia in 1999. In all of the countries relative regional wages subsequently recovered and started converging to the wage level in the central region. Furthermore, Figures $2 \mathrm{a}$ and $2 \mathrm{~b}$ demonstrate that along with the process of recovering of the average relative regional wages one can also observe a clear trend of $\sigma$-convergence shown in the fact that the standard deviation of regional wages decreased in all of the countries after regional wages reached the lowest point. In other words, one can simultaneously observe a U-shaped adjustment pattern of relative regional wages and an inverted U-shaped trend of variation of regional wages. This can be taken as an indication of $\sigma$-divergence of regional wages in the first stage of trade liberalisation and of $\sigma$-convergence of regional wages towards the end of the period under examination. We believe that with longer time panels of regional data these trends would become even more pronounced.

The second important issue that requires closer examination are the differences in adjustment pattern of relative wages between $\mathrm{W} / \mathrm{N}$ border and non-border regions. Our model predicts that after the initial downturn W/N border regions will attract new firms and start catching up with the central region at a faster pace than non-border regions. 

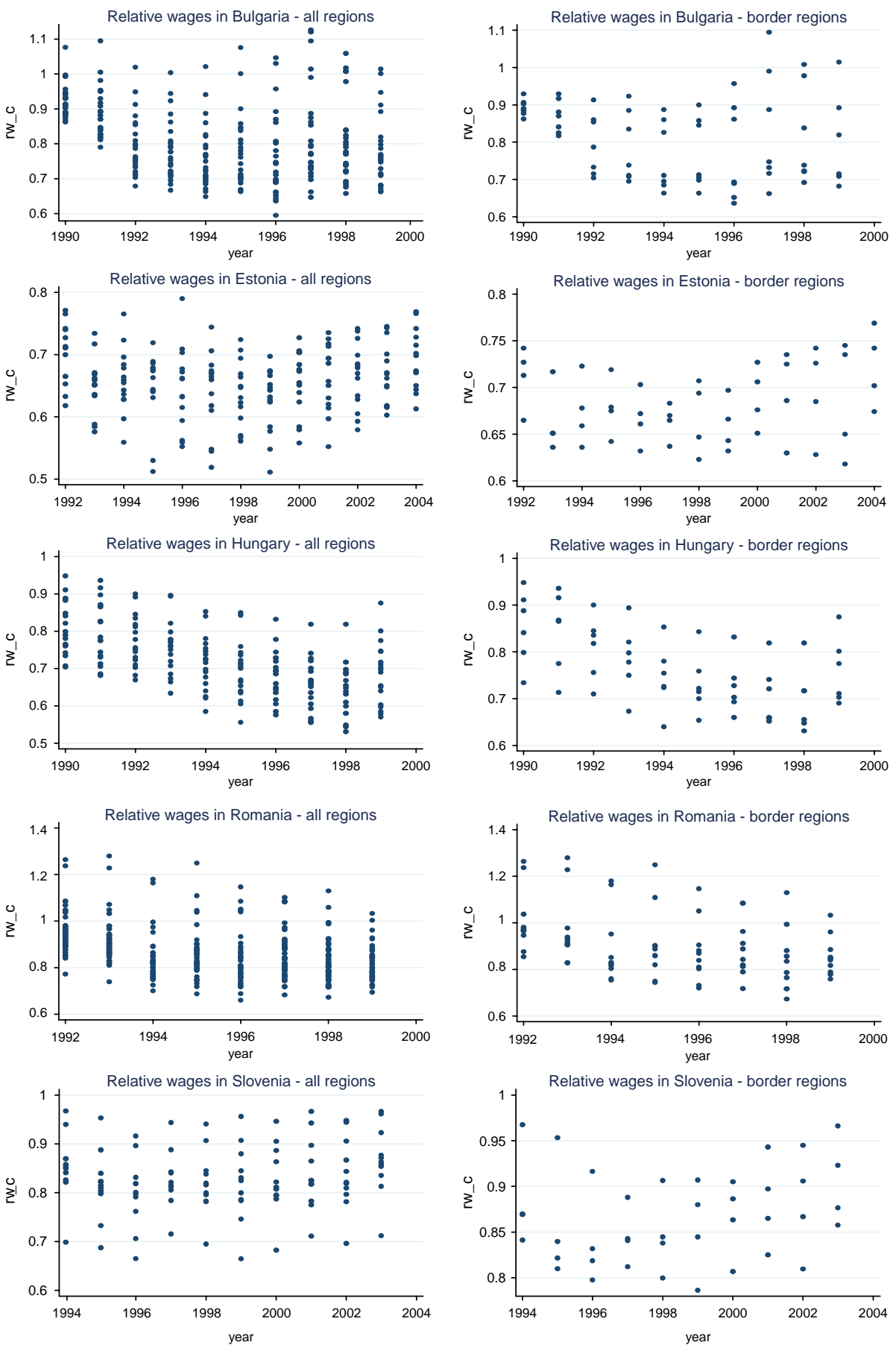

Figure 1. Pattern of relative regional wages in transition countries, 1990-2004. 

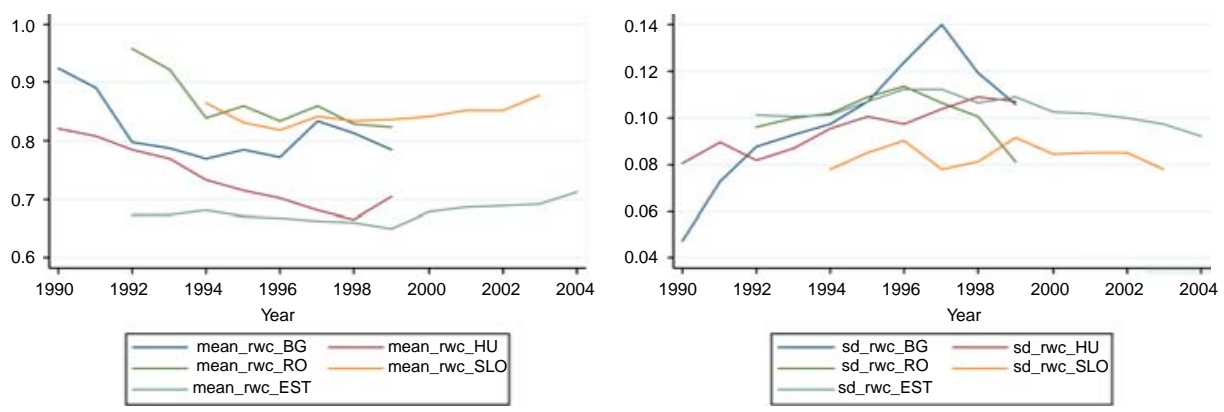

Figure 2. Properties of relative wages (means and standard deviations) by countries, 1990-2004.
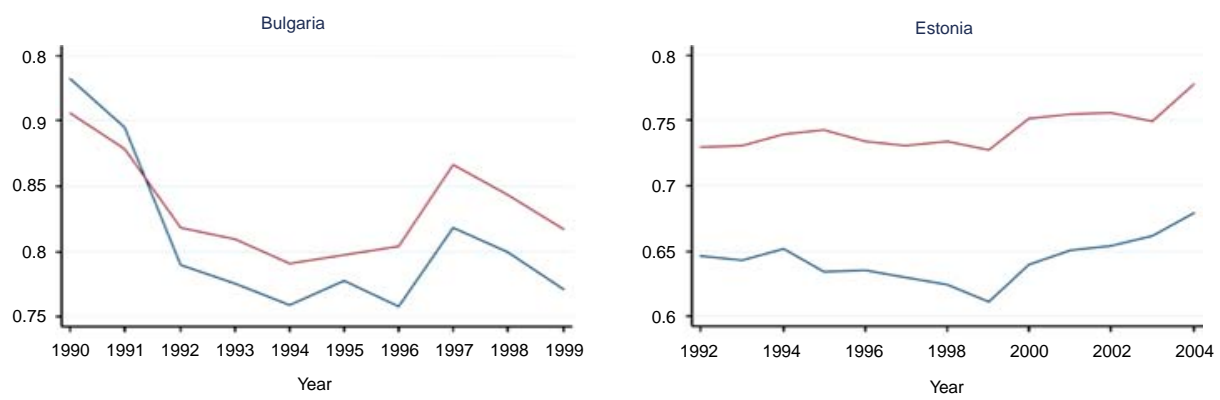

- nonb_rmc_BG $\longrightarrow$ bord_rmc_BG

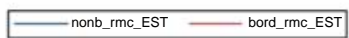

Hungary
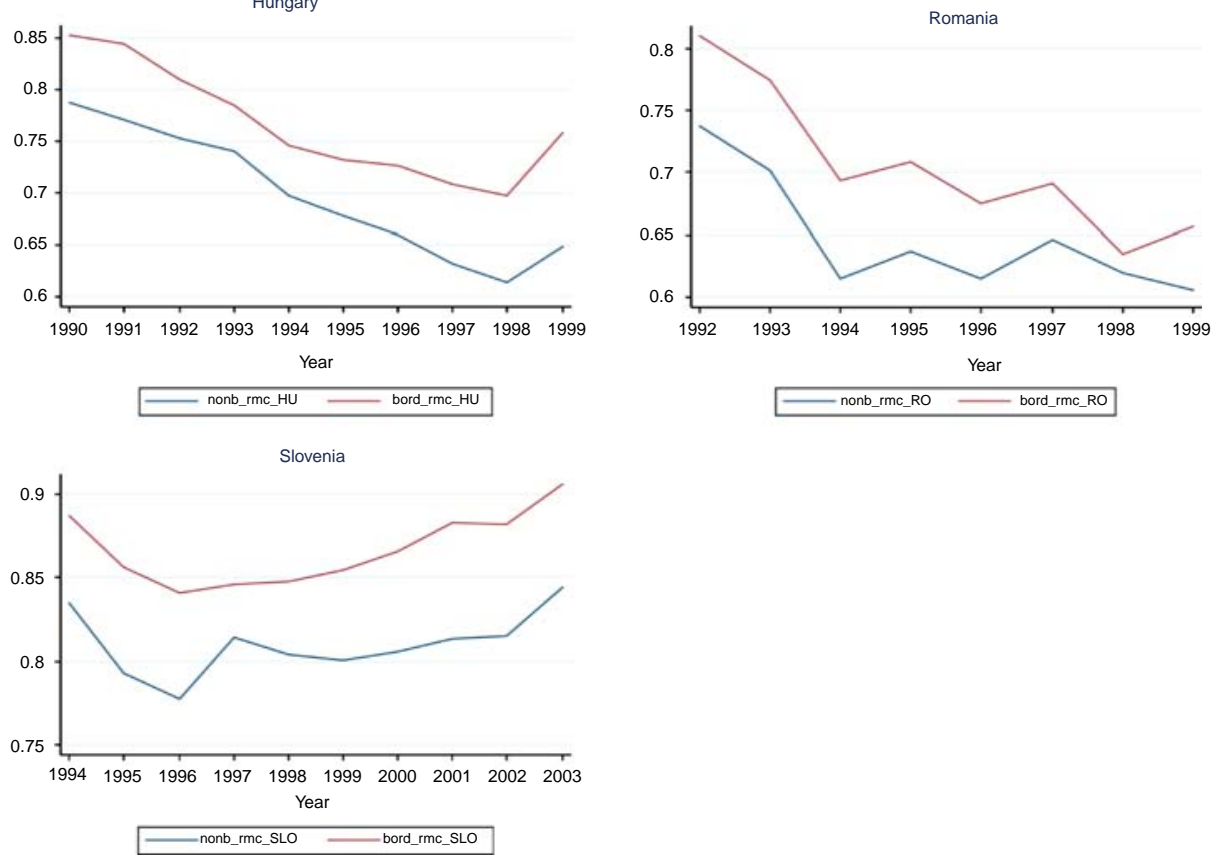

Figure 3. Mean relative regional wages in $\mathrm{W} / \mathrm{N}$ border and non-border regions, by countries 1990-2004. 
A number of studies for individual CEE countries (Traistaru et al. 2003) confirm these predictions by showing a clear trend of manufacturing activity shifting towards either the capital or the W/N border regions during the 1990s. As a consequence, relative regional wages adjusted accordingly. Figure 3 shows that after countries opened up to trade, relative wages in $\mathrm{W} / \mathrm{N}$ border regions decreased at a lower rate and started recovering earlier and at a faster pace than in non-border regions. These trends are particularly pronounced in Bulgaria, Estonia, Hungary and Slovenia. With the exception of Romania, in all the countries the wage differential between the W/N border and non-border regions increased over the period. It remains to be shown how much of this faster adjustment pattern in $\mathrm{W} / \mathrm{N}$ border regions can be attributed to increased economic activity brought about by FDI.

\section{Evolution of relative regional $\mathrm{FDI}$}

As shown in Table 2, the selected CEE countries received substantial FDI inflows during the 1990s. The share of all CEE countries in world FDI flows increased from $0.2 \%$ in 1990 to $2.3 \%$ in 2000 (World Investment Report 2001). In the countries under examination the stock of FDI throughout the 1990s accumulated to some 15-50\% of GDP. The major recipient of FDI in absolute terms among the selected countries was Hungary, while in relative terms (as a share of GDP) FDI played the most important role in Estonia.

Figure 4 depicts the pattern of relative regional presence of foreign-invested enterprises (FIEs) ${ }^{10}$ in W/N border and non-border regions in individual countries. ${ }^{11}$ Here, in the absence of more appropriate data, the number of FIEs relative to the number of domestic firms serves as an effective measure of the regional importance of FDI. As discussed earlier, these indicators should be interpreted with considerable caution. As we use only data on the number of firms and not on their output, this may introduce some bias into our findings.

Figure 4 shows that, with the noted exception of Slovenia, FDI inflows in CEE countries are very polarised since the vast majority of FDI inflows into manufacturing industries is directed into the capital region. On average, the share of FDI in other regions is well below $10 \%$ and in Romania even below $5 \%$ of the level achieved by the central region. This evidence is in line with the findings of Alessandrini and Contessi (2001) who found that the majority of FDI inflows in CEE countries have been directed into the central regions and traditional economic centres. ${ }^{12}$ Nevertheless, the regional pattern of manufacturing FDI does, by and large, correspond to the one suggested by our model. First of all, in all five countries the relative regional shares of FDI in W/N border regions are substantially (up to three times) higher than in non-border regions. Second, this differential increased further with the process of trade liberalisation as W/N border regions succeeded in attracting relatively more FDI than non-border regions. To sum up, as W/N border regions continue to receive larger FDI inflows than other peripheral regions they should therefore exhibit relatively faster economic growth and faster catch-up of relative wages compared with the central region.

\section{Results}

\section{Econometric approach}

Before we turn to the estimation results of our empirical model (2), a few words need to be said about the methodology of estimations. There are two important issues to be discussed with respect to the specification of model (2). The first is the importance of idiosyncratic 


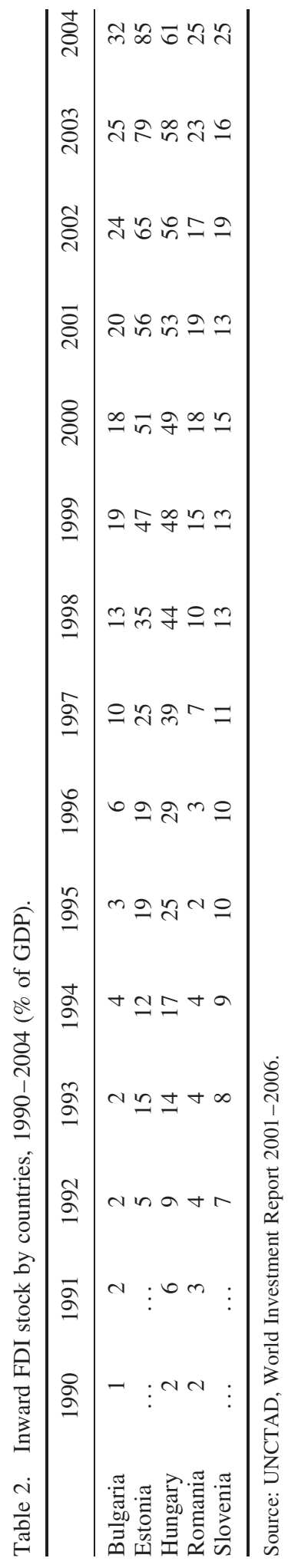



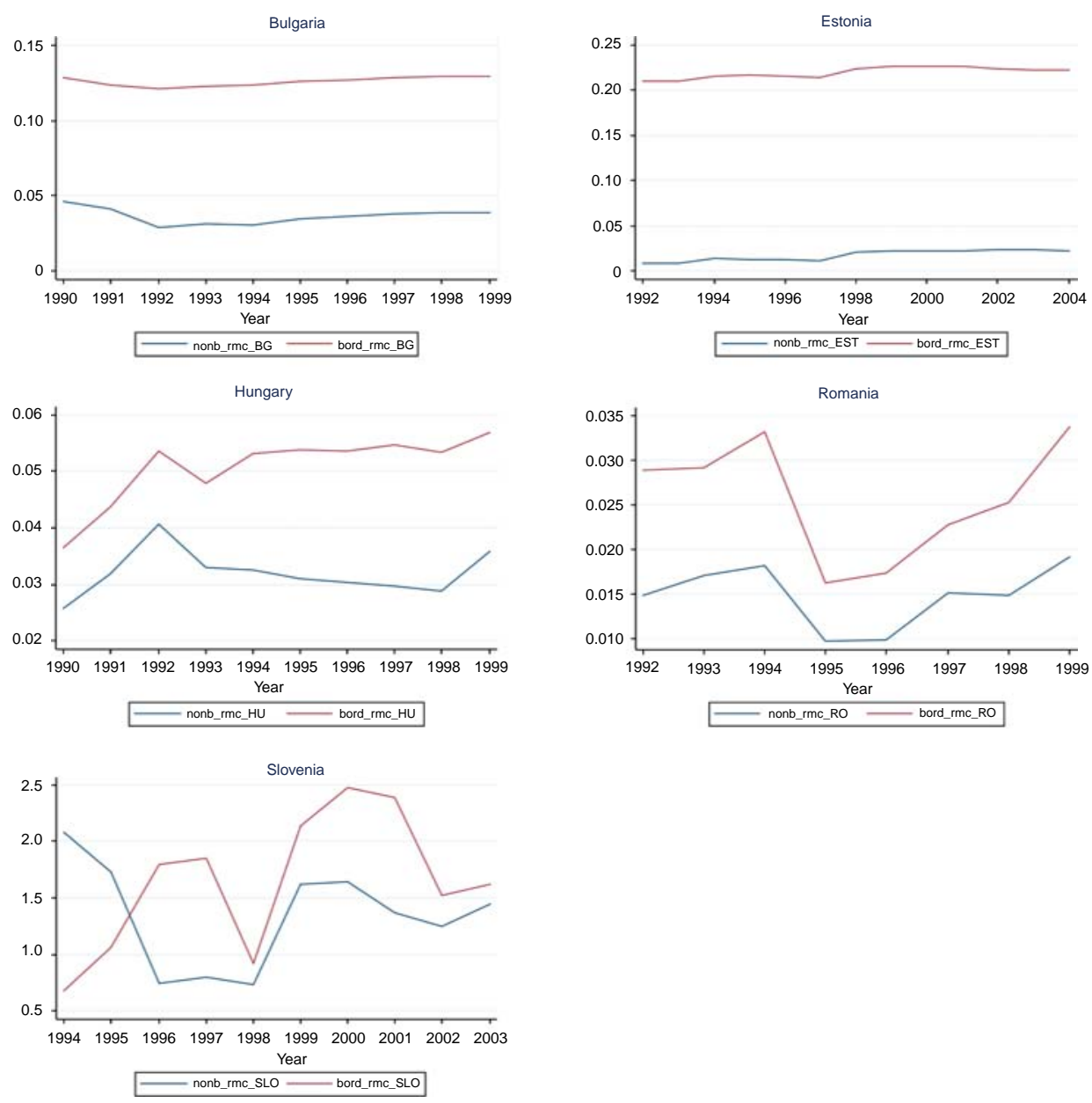

Figure 4. Mean relative regional FDI in W/N border and non-border regions by countries, 1990-2004.

regional effects in the panel data framework due to the specific structure of the error term, and the second is the problem of potential endogeneity between relative regional wages and FDI.

First, in the above empirical model strong individual regional effects can be expected. Therefore, one must make specific assumptions regarding the error structure. We assume the error term $u_{i t}$ has the following properties:

$$
\begin{gathered}
u_{i t}=\eta_{i}+e_{i t}(i=1, \ldots, n ; t=1, \ldots, T) \\
E\left[\eta_{i} / x_{i t}\right] \neq 0 \quad \text { and } E\left[e_{i t} / x_{i t}, \eta_{i}\right]=0 \\
e_{i t} \sim N\left(0, \sigma^{2}\right)
\end{gathered}
$$

According to Equation (3), we assume that some unobserved individual regional effects are present $\left(\eta_{i}\right)$, which are time-invariant and correlated with the right-hand side regressors in Equation (2). The remaining disturbances $\left(e_{i t}\right)$ are assumed to be normally 
distributed with zero mean and constant variance. Note that for the sake of convenience henceforth we will refer to specification (2) as the static specification of the model. Our data are structured as regional panel data for a time span of 7-13 years (depending on the country in question), which requires an explicit account of the region-specific effects. With the above structure of the model the use of an ordinary least squares (OLS) estimator is not justified anymore and one should adopt one of the usual estimators dealing with individual effects. In general, when using a static specification of the empirical model in a panel data framework there are two well-known ways of controlling for this bias. The first option is to employ the fixed effects (FE) estimator, which assumes fixed (constant) region-specific effects over time, which are correlated with the right-hand side regressors. On the other hand, the random effects (RE) estimator assumes that region-specific effects are random and only reflected in the error term, i.e. uncorrelated over time. We are interested in observing the pattern of changes in relative regional performance over time induced by external shocks such as trade liberalisation. Given that different regions are likely to respond idiosyncratically to trade liberalisation, the FE estimator seems the natural choice. Therefore, in Equation (3) we specify our assumptions about the structure of the error term, which enables us to take explicit control of these effects. An important drawback of the FE estimator in the present case, however, is that some of the crucial variables in our empirical model are time-invariant (such as border dummies and the trade liberalisation dummy). When performing regular FE estimations these variables are differenced out and therefore dropped from the estimation procedure. In order to avoid this, we decided to employ the RE estimator as it allows us to obtain estimates of the timeinvariant BORD and FTA variables as well.

Another important issue is that even though FDI may be modelled as an exogenous occurrence the actual regional pattern of FDI inflows is not independent of regional characteristics. On the contrary, the regional pattern of FDI is determined endogenously as it is attracted to domestic regions according to either agglomeration forces or lower relative regional wages. An important consequence of this is the endogeneity between relative regional wages $\left(r W_{i t}\right)$ and relative regional FDI $\left(r F D I_{i t}\right)$ in the specification of our model. This means that model (2) captures dynamic processes in the regions as the current inflow of FDI is determined endogenously by previous relative regional wages, and present FDI determines future relative regional wages. More specifically, the endogeneity between $r W_{i t}$ and $r F D I_{i t}$ implies that the error term $u_{i t}$ is correlated with $r F D I_{i t}$. This can be seen clearly if the error term $u_{i t}$ is rewritten accordingly:

$$
u_{i t}=\eta_{i}+\left(\nu_{i t}+m_{i t}\right) \quad(i=1, \ldots, n ; t=1, \ldots, T)
$$

with the assumptions

$$
\begin{aligned}
& \nu_{i t}=\rho \nu_{i t-1}+e_{i t} \\
& e_{i t}, m_{i t} \sim \operatorname{MA}(0)
\end{aligned}
$$

where the remaining error term $e_{i t}$ is decomposed into $\nu_{i t}$ which is an autoregressive regional shock, while $m_{i t}$ represents serially uncorrelated measurement error. Note that all RHS regressors in model (2) are potentially correlated with region-specific effects $\eta_{i}$ as well as with both autoregressive shocks $\nu_{i t}$ and measurement errors $m_{i t}$.

The time dimension of panel data enables us to capture these dynamics of adjustment directly by including the lagged dependent as well as lagged independent variables. 
Hence, a dynamic version of the relative regional wage model (2) can then be written as

$$
\begin{aligned}
r W_{i t}= & \rho r W_{i t-1}+\nu t+\omega t^{2}+\varphi r F D I_{i t}+\rho \varphi r F D I_{i t-1}+\gamma B O R D_{i}+\lambda F T A \\
& +\eta_{i}(1-\rho)+e_{i t}+\left(m_{i t}-\rho m_{i t-1}\right)
\end{aligned}
$$

In the above dynamic specification of the model we have perfect simultaneity as not only are present and lagged dependent variables correlated but also lagged dependent variables (wages) are assumed to be correlated with present independent variables (FDI) and vice versa. Applying the OLS estimator to model specification (5) would inevitably lead to inconsistent and biased coefficients. The OLS estimator is unbiased and consistent when all explanatory variables are exogenous and are uncorrelated with the individual specific effects. This, however, is not the case in our model, which includes lagged variables. One can show that the OLS estimator will be seriously biased owing to correlation of the lagged dependent variable with the individual specific effects as well as with the independent variables. This is due to the fact that $r W_{i t}$ is a function of $\eta_{i}$ in Equation (5), and then $r W_{i t-1}$ is also a function of $\eta_{i}$. As a consequence, $r W_{i t-1}$ is correlated with the error term, which renders the OLS estimator biased and inconsistent, even if the $\nu_{i t}$ and $m_{i t}$ in Equation (4) are not serially correlated. This holds also whether the individual effects are considered fixed or random (see Hsiao 1986, Baltagi 1995, Wooldridge 2002).

Therefore, in estimating (5) one should use one of the usual instrumental variable methods that are applied in the dynamic panel data framework. A natural choice of approach that allows us to control for the unobserved heterogeneity and simultaneity in Equation (5) is application of GMM (general method of moments) estimators (Arellano and Bond 1991). There are two possible choices of application of the GMM approach to dynamic panel data. The difference GMM (diff-GMM) method uses lagged levels as instruments for first-differenced equations. However, as shown by Arellano and Bover (1995), lagged level instruments used in the diff-GMM approach are weak instruments for first-differenced equations. Arellano and Bond (1998) and Blundell and Bond (1998, 1999) suggest that application of system GMM (sys-GMM) estimators is a more appropriate approach to dynamic panel data than using diff-GMM estimators. If the model is estimated in levels, the corresponding instruments for $x_{i t-3}$ are $x_{i t-1}, x_{i t-2}$ and $\Delta x_{i t-1}$ (where $x$ stands generally for all included variables) and so on for longer time periods. This approach allows for a larger set of lagged levels and first-differences instruments and therefore enables us to exploit fully all of the available moment conditions. Hence, the system GMM approach maximises both the consistency and the efficiency of the estimator applied. The only drawback of the sys-GMM approach to dynamic panel data is that either balanced panel data or longer time series are required since the first two years of observations are used up as instruments.

\section{Results of the static model specification}

In this section we provide basic estimation results of our empirical model (2) using OLS and RE estimators. ${ }^{13}$ Table 3 provides OLS estimations which serve as a benchmark for comparison with RE estimations as well as the GMM estimations following in the next subsection. Overall, the OLS results are in line with our expectations and can be summarised as follows. First, in all the countries, with the exception of Romania, the estimations return negative and significant coefficients for the trend variable $t$ and positive and significant coefficients on the squared trend variable $t^{2} \cdot{ }^{14}$ This result conforms to our 


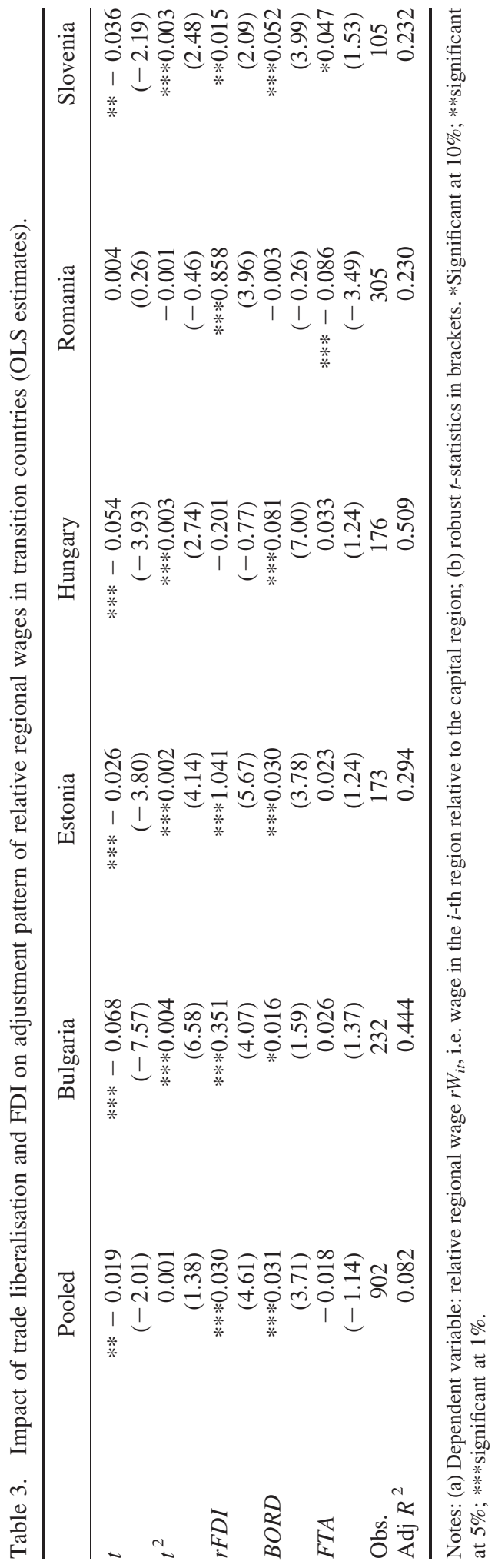


predictions of a U-shaped response of relative regional wages to trade liberalisation. Second, in all the countries, with the exception of Hungary, the estimated coefficient of relative regional FDI $\left(r F D I_{i t}\right)$ is significantly positive. Hence FDI is shown to contribute positively to the actual pattern of adjustment of regional wages. For Hungary, the finding of insignificant impact of FDI on regional wages comes as a surprise, since Hungary attracted large inflows of foreign capital during the 1990s. The obvious explanation for this finding is that the vast majority of FDI in Hungary has been directed to the central region, and has in turn not contributed to regional convergence of wages. Third, the coefficient $B O R D$ is significantly positive in all the countries, with the exception of Romania, indicating that border regions do have higher wages due to higher economic concentration. The wage differential between $\mathrm{W} / \mathrm{N}$ border regions and the other regions ranges between 1.6 and $8.1 \%$ depending on the country in question, while the average wage premium of $\mathrm{W} / \mathrm{N}$ border regions over all of the countries amounts to $3.1 \%$.

The RE estimations (Table 4) which control for common regional effects almost entirely replicate the OLS estimations. A U-shaped response of relative regional wages to trade liberalisation is confirmed for all the countries except Romania. The average wage differential between W/N border and non-border regions over all of the countries is estimated at $3.3 \%$ (compared with $3.1 \%$ in the case of OLS estimates). These estimates are similar to those obtained by Brülhart and Koenig (2006), who estimate average wage gradients of border regions in five CEE countries at $2.7 \%$. $^{15}$ The only significant difference from the OLS estimations is that the RE estimations do not return a significant effect of relative regional FDI $\left(r F D I_{i t}\right)$ for Romania, while with OLS the coefficient for $r F D I_{i t}$ was significantly positive and very large.

\section{Results of the dynamic model specification}

In this section we provide robustness checks for the OLS and RE estimations by estimating the dynamic specification of model (5). We apply the sys-GMM econometric method allowing instruments (levels and first differences) to take up to four lags. In Table 5 we report estimations of the coefficients taken from the first step estimations, while the specification tests are taken from the second step estimations. ${ }^{16}$ Note that owing to the correlation with the FTA dummy that arises in the instrumentalisation process the squared time trend $t^{2}$ is dropped from all individual country specifications. As the U-shaped nature of the adjustment pattern of relative wages has been confirmed by earlier estimations we focus on the other two crucial variables-the impact of relative FDI and the border effects on relative wages.

The GMM estimations, which control for simultaneity between the relative regional wages and FDI, closely resemble the results obtained by RE estimations. As with the RE estimations, the dynamic estimations find a significant impact of relative regional FDI on relative regional wages in Bulgaria, Estonia and Slovenia. Similarly, the estimated coefficients of the border effects on relative regional wages are close to those obtained by the OLS and RE estimations. The average wage differential between W/N border and nonborder regions over all of the countries is estimated at $2.7 \%$ (compared with to 3.1 and $3.3 \%$ in the case of OLS and RE estimates respectively). The same is true for individual country estimations of wage gradients of border regions, which are accordingly lower than those obtained by the OLS and RE estimations.

These findings are in line with the predictions of the Crozet-Koenig (2004) model showing that trade liberalisation generally favours the development of the border region when competitive pressure from international markets is not too high. Crozet and Koenig 


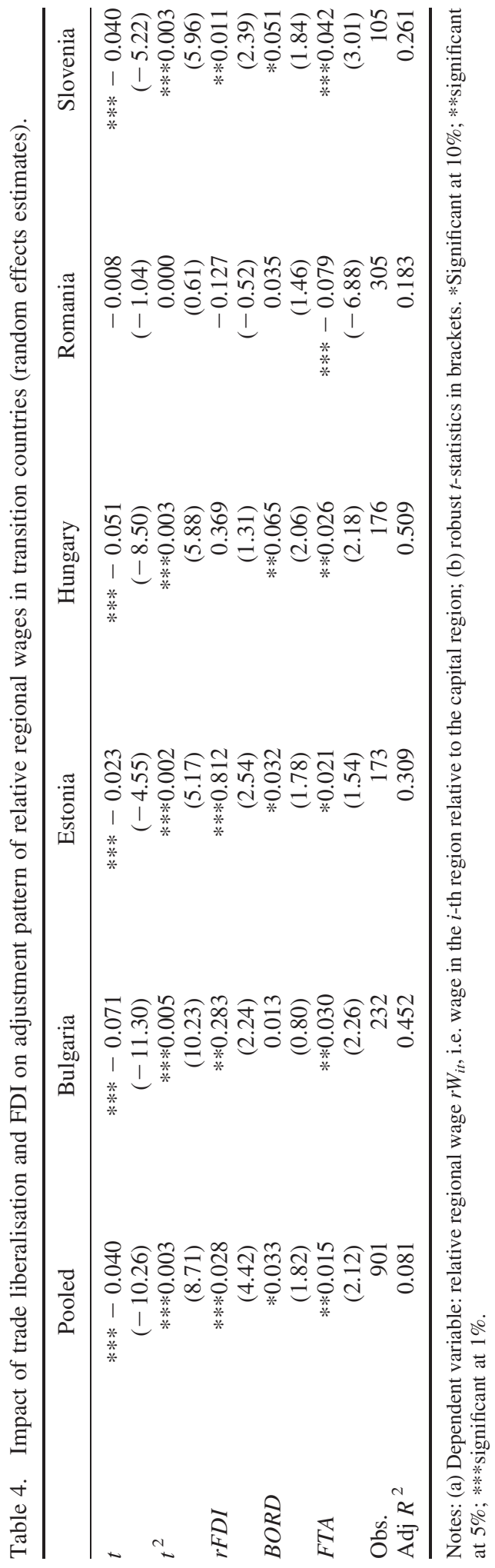




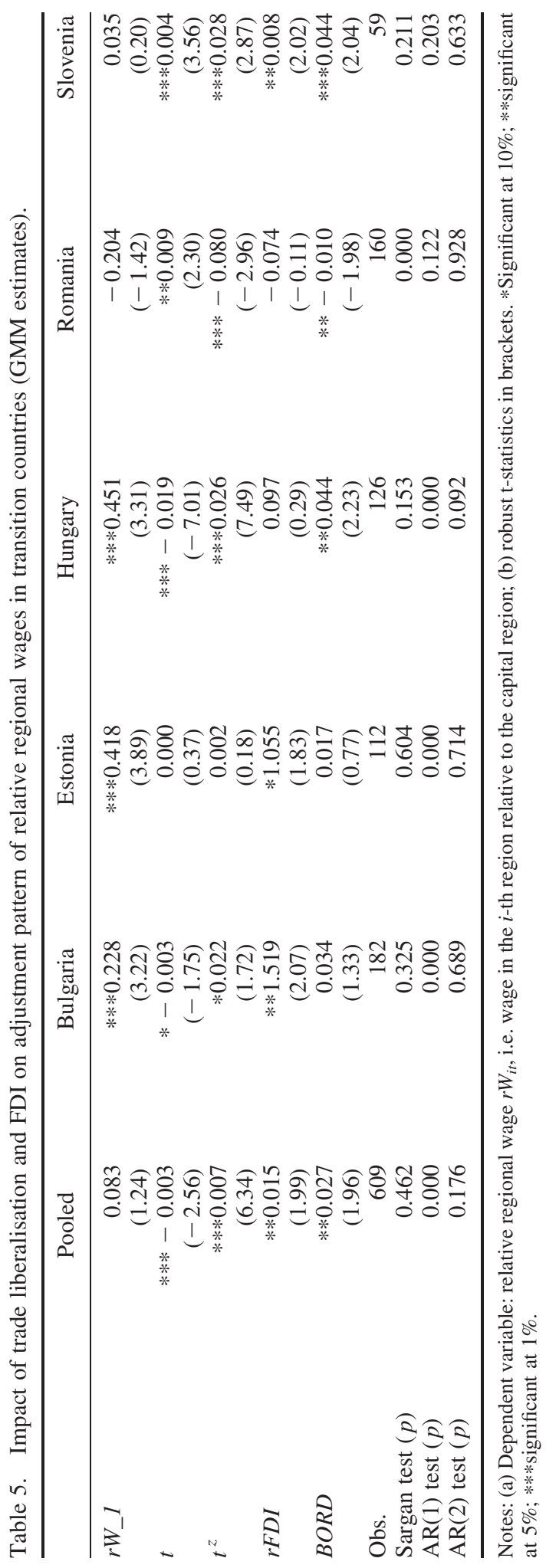


also use data for Romanian NUTS-3 regions for 1990-97 and claim to confirm this thesis. They, however, test a different model not directly comparable with ours. They show that urbanisation of the regions is driven by the initial level of urbanisation and initial market potential, while a high nominal wage level in particular is shown to favour urban growth. This means that trade liberalisation fosters growth of the existing economic centres in Romania. This finding is in line with our results as we do not find higher wage levels in the Romanian W/N border regions, indicating that there was not much relocation of economic activity towards border regions after trade liberalisation started.

\section{Conclusions}

This article analyses the effects of trade liberalisation with the EU on inter-regional relocation of manufacturing and inter-regional adjustment of relative wages in five CEE countries. Based on the general principles of new economic geography theory and acknowledging the specifics of the countries in the sample, we expected that trade liberalisation might have a dual effect on the distribution of economic activity across the sampled regions of Central and Eastern Europe. Our assumption of asymmetric location of domestic regions vis-à-vis the EU markets, combined with relatively low labour mobility, would tend to lead to a typical non-monotonic, U-shaped response of relative regional wages to trade liberalisation. Our second focal point was the impact FDI flows could have on the direction and speed of the adjustment process. While foreign investment directed at specific regions could certainly accelerate the adjustment process, its ultimate impact depends on whether foreign investors target economic centres or $\mathrm{W} / \mathrm{N}$ border regions in EU accession countries.

In the second part of the article we turn to examination of the actual pattern of manufacturing relocation and the adjustment pattern of relative regional wages in five CEE countries after they liberalised their trade with the EU. Two empirical issues are of particular interest to us. First, we study whether the response of relative regional wages to trade liberalisation is non-monotonic. In additions, we test whether the pattern of regional FDI inflows, falling trade costs after trade liberalisation and the relocation of manufacturing activity towards western/northern regions can explain the adjustment pattern of relative regional wages in the five CEE countries. These implications are tested using a unique regional data panel for Bulgaria, Estonia, Hungary, Romania and Slovenia in 1990-2004.

Our estimates show that notwithstanding the econometric method used (OLS, RE and GMM estimations) the predictions of our model are robustly confirmed. We find very strong evidence that, in most of the CEE countries analysed, trade liberalisation caused a decline and divergence of relative regional wages, but the relative wages then adjusted to the shock mainly by economic geography factors. A U-shaped response of relative regional wages to trade liberalisation is confirmed for all countries except Romania. On the other hand, with lower international trade costs, the western/northern border regions closer to the EU economic centres benefitted most in terms of economic activity by attracting domestic as well as foreign firms. It is shown that international flows of capital, as the most mobile factor of production, contributed significantly to the faster adjustment of economic activity and to faster convergence of relative regional wages after trade liberalisation in at least three out of the five CEE countries.

To summarise our findings, we can conclude that in CEE countries important interregional relocations of manufacturing activity took place after trade liberalisation with the EU and that inflows of FDI mostly to the capital and border regions helped foster these 
adjustment processes. However, as economic integration with the EU provides important opportunities for individual regions, it can also have severe polarisation effects. Based on our findings, policy makers in the affected CEE countries should be careful to design appropriate policy measures to either foster the adjustment processes in more fortunate regions or help overcome the polarisation effects in less fortunate regions. In line with the suggestions by Traistaru et al. (2003) policy makers should in particular aim at further economic restructuring within the prospering regions, at attracting foreign direct investment as well as at enhancing the innovative and technological potential of local firms by building up the scientific and technological capabilities of local labour and firms. For regions that have lesser locational advantages income polarisation is likely to be more severe. To overcome this, policy makers should concentrate on upgrading local infrastructure, developing schemes for supporting local entrepreneurship as well as human resources development. As shown by Bellak et al. (2009), while CEE countries mostly attract FDI by favourable corporate taxes schemes, a favourable infrastructure endowment may compensate for relatively high taxes. At the same time, as shown by Baldwin et al. (2003), policy makers should be aware of the fact that most of their policy measures might have non-linear effects. For example, improvement of infrastructure in a poor domestic region may have no effect until a certain threshold is reached where convergence occurs between poor and rich regions. On the other hand, improvements in infrastructure that facilitate trade between regions may have no effect until a certain threshold is reached where divergence occurs between the two regions. This calls for very careful and thoughtfully designed regional economic policies.

\section{Acknowledgements}

We gratefully acknowledge financial support from the European Commission within the PHARE ACE Programme 'European integration, regional specialisation and location of industrial activity in accession countries' (Contract No. P98-1117-R) and within the RTD 5th FP research project EURECO 'The impact of European integration and enlargement on regional structural change and cohesion' (Contract No. HPSE-CT-2002-00118).

\section{Notes}

1. Similar results, with trade liberalisation favouring the development of EU-bordering regions, are also found by Resmini (2003) and Brülhart et al. (2004).

2. Further support for the proposed divergence - convergence type of adjustment of relative wages after trade liberalisation is found also at the national level. Polanec (2004) examines the hypotheses of absolute and conditional convergence for a sample of 25 transition countries over 1990-2002. He finds a negative relationship between productivity growth and the pace of liberalisation at the initial stage of transition (1990-94), while at the later stages (1999-2002) evidence is found in favour of convergence of productivity levels among the countries under examination.

3. A comprehensive overview of alternative NEG models is given in Fujita et al. (1999).

4. See for instance Fidrmuc (2005) and Transition Report (2003) where very low migration intensity within transition countries is observed.

5. The empirical specification also includes higher order values of time trends to test for the possible concavities of the temporal response of relative regional wages.

6. Note that relative FDI inflows into the economic centre would further stimulate the initial divergence (increase the relative wage difference), while inflows targeting primarily the N/W border regions would stimulate the convergence in wages.

7. Estonia could also be considered an EU-bordering country, but only conditionally as it shared only a sea border with the EU (Finland and Sweden).

8. PHARE ACE Programme research project 'European integration, regional specialisation and location of industrial activity in accession countries' (Contract No. P98-1117-R) and the RTD 
5th FP research project EURECO 'The impact of European integration and enlargement on regional structural change and cohesion' (Contract No. HPSE-CT-2002-00118). Both projects were financed by the European Commission.

9. Another advantage of this study is that we have access to longer panels of regional data than previous studies on transition countries. In this way we believe we have the opportunity to study the complete adjustment pattern of regional economic activity and wages and the underlying factors affecting these processes.

10. We consider all enterprises where foreign ownership constitutes at least $10 \%$ of the ownership structure as foreign-owned enterprises.

11. Table A2 in the Appendix for more detailed descriptive statistics on the regional pattern of FDI.

12. In the late 1990s some governments (e.g. Bulgaria and Romania) started to actively attract foreign capital into disadvantaged and poorer regions, which is likely to benefit all regions.

13. In order to assess the robustness of the estimated coefficients on the impact of FDI on wages $\left(r F D I_{i t}\right)$ we also ran FE estimates. We find the sign and significance (but not the size) of the $r F D I_{i t}$ coefficients very closely resemble those obtained by the RE estimations.

14. Time trend variables to the third and fourth power have also been included in various specifications further confirming the empirical relevance of the proposed U-shaped response curve.

15. Note however that Brülhart and Koenig (2006) estimate wage gradients for a different set of transition countries (Czech Republic, Hungary, Poland, Slovenia and Slovakia) and for a different period (1996-2000).

16. In Table 5 we omit reporting the coefficients on the lagged relative regional FDI $\left(r F D I_{i t-1}\right)$.

\section{References}

Alessandrini, S. and Contessi, S., 2001. The regional location of FDI in Central Europe: an empirical analysis in a comparative perspective, Mimeo, Bocconi University.

Alonso-Villar, O., 1999. Spatial distribution of production and international trade: a note. Regional science and urban economics, 29 (3), 371-380.

Arellano, M. and Bond, S.R., 1991. Some tests of specification for panel data: Monte Carlo evidence and an application to employment equations. Review of economic studies, 58, 277-297.

Arellano, M. and Bond, S.R., 1998. Dynamic panel data estimation using DPD98 for GAUSS, Mimeo, Institute for Fiscal Studies, London.

Arellano, M. and Bover, O., 1995. Another look at the instrumental-variable estimation of errorcomponents models. Journal of econometrics, 68, 29-52.

Baldwin, R. et al., 2003. Economic geography and public policy. Princeton: Princeton University Press.

Baltagi, H.B., 1995. Econometric analysis of panel data. Chichester: John Wiley \& Sons.

Bellak, C., Damijan, P.J. and Leibrecht, M., 2009. Infrastructure endowment and corporate income taxes as determinants of foreign direct investment in Central and Eastern European countries. The world economy, 32 (2), 267-290.

Blundell, R.W. and Bond, S.R., 1998. Initial conditions and moment restrictions in dynamic panel data models. Journal of econometrics, 87, 115-143.

Blundell, R.W. and Bond, S.R., 1999. GMM estimation with persistent panel data: an application to production functions, Working paper no. W99/4. London: Institute for Fiscal Studies.

Brakman, S., Garretsen, H. and Schramm, M., 2004. The spatial distribution of wages: estimating the Helpman-Hanson model for Germany. Journal of regional science, 44, 437-466.

Braunerhjelm, P. and Thulin, P., 1974. Agglomeration, relative wage costs and foreign direct investment - evidence from Swedish MNCs 1974-1998. Journal of industry, competition and trade, 9, 197-217.

Brülhart, M., Crozet, M. and Koenig, P., 2004. Enlargement and the EU periphery: the impact of changing market potential. World economy, 27, 853-875.

Brülhart, M. and Koenig, P., 2006. New economic geography meets Comecon. Economics of transition, 14, 245-267.

Brülhart, M. and Torstensson, J., 1996. Regional integration, scale economies and industry location in the European Union, CEPR discussion paper no. 1435.

Crozet, M. and Koenig, P., 2004. EU enlargement and the internal geography of countries. Journal of comparative economics, 32, 265-279. 
Damijan, P. and Kostevc, C., 2008. Trade liberalization and economic geography in transition countries: can FDI explain the adjustment patterns of regional wages?, LICOS discussion papers 22208.

Damijan, P.J. and Rojec, M., 2007. Foreign direct investment and catching up of new EU member states: is there a flying geese pattern? Applied economics quarterly, 53 (2), 91-118.

Egger, P., Huber, P. and Pfaffermayr, M., 2005. A note on export openness and regional wage disparity in Central and Eastern Europe. Annals of regional science, 39, 63-71.

Fidrmuc, J., 2005. Labor mobility during transition: evidence from Czech Republic, William Davidson Institute working paper, no. 767.

Forslid, R., Haaland, J.I. and Midelfart Knarvik, K.H., 2002. A U-shaped Europe? A simulation study of industrial location. Journal of international economics, 57, 273-297.

Fujita, M., Krugman, P. and Venables, A.J., 1999. The spatial economy: cities, regions, and international trade. Cambridge, MA: MIT Press.

Hanson, G.H., 1996. Economic integration, intra-industry trade, and frontier regions. European economic review, 40, 941-950.

Hanson, G.H., 1997. Increasing returns, trade and the regional structure of wages. The economic journal, 107, 113-132.

Hanson, G.H., 2005. Market potential, increasing returns, and geographic concentration. Journal of international economics, $67,1-24$.

Helpman, E., 1998. The size of regions. In: D. Pines, E. Sadka and I. Zilcha, eds. Topics in public economics. Cambridge: Cambridge University Press.

Hsiao, C., 1986. Analysis of panel data. Cambridge, MA: Cambridge University Press.

Jones, J. and Wren, C., 2006. Foreign direct investment and the regional economy. Aldershot: Ashgate Publishing.

Krugman, P., 1991a. Geography and trade. Cambridge, MA: MIT Press.

Krugman, P., 1991b. Increasing returns and economic geography. Journal of political economy, 99, 483-499.

Krugman, P. and Livas Elizondo, R., 1996. Trade policy and third world metropolis. Journal of development economics, 49, 137-150.

Krugman, P. and Venables, A.J., 1995. Globalization and the inequality of nations. Quarterly journal of economics, 110, 857-880.

Krugman, P. and Venables, A.J., 1996. Integration, specialization, and adjustment. European economic review, 40, 959-968.

Mion, G., 2004. Spatial externalities and empirical analysis: the case of Italy. Journal of urban economics, 56, 97-118.

Monfort, P. and Nicolini, R., 2000. Regional convergence and international integration. Journal of urban economics, 48, 286-306.

Neary, J.P., 2001. Of hype and hyperbolas: introducing the new economic geography. Journal of economic literature, 39, 536-561.

Paluzie, E., 2001. Trade policies and regional inequalities. Papers in regional science, 80 (1), $67-85$.

Polanec, S., 2004. Convergence at last? Eastern European economics, 42 (4), 55-80.

Puga, D., 1999. The rise and fall of regional inequalities. European economic review, 43, 303-334.

Puga, D. and Venables, A.J., 1996. The spread of industry: spatial agglomeration and economic development. Journal of the Japanese and international economies, 10, 440-464.

Puga, D. and Venables, A.J., 1997. Preferential trading arrangements and industrial location. Journal of international economics, 43, 347-368.

Resmini, L., 2003. Economic integration, industry location and frontier economies in transition countries. Economic systems, 27, 205-221.

Rojec, M., Redek, T. and Kostevc, C., 2010. Analysis of the efficiency of investment incentives in Central and Eastern Europe, Faculty of Economics Mimeo, University of Ljubljana.

Traistaru, I., Nijkamp, P. and Resmini, L., eds, 2003. The emerging economic geography in EU accession countries. Aldershot: Ashgate.

Transition report 2003: Integration and regional cooperation, London: EBRD.

Wooldridge, J., 2002. Econometric analysis of cross section and panel data. Cambridge, MA: MIT Press, World Investment Report 2001, 2006. Geneva: UNCTAD. 


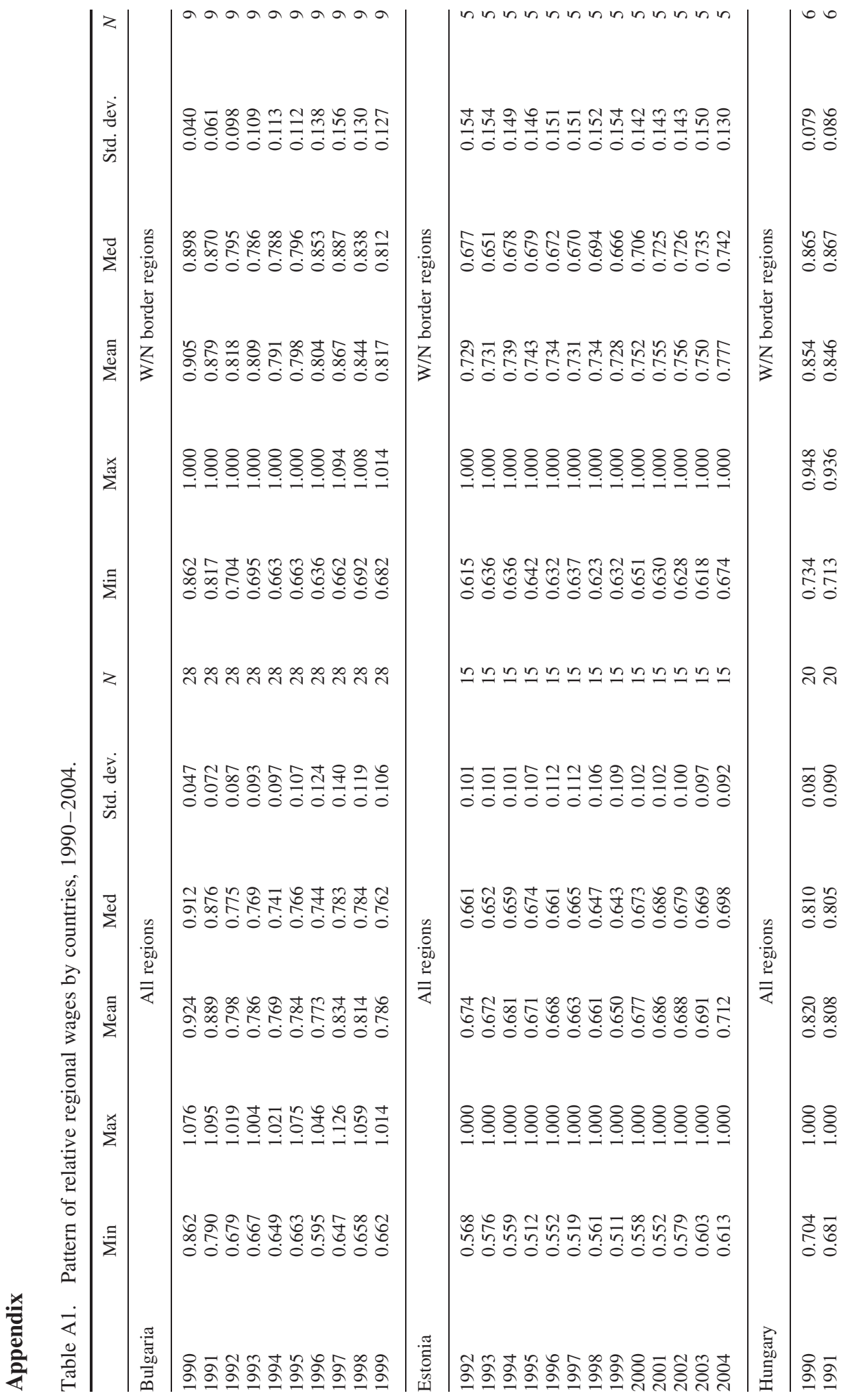




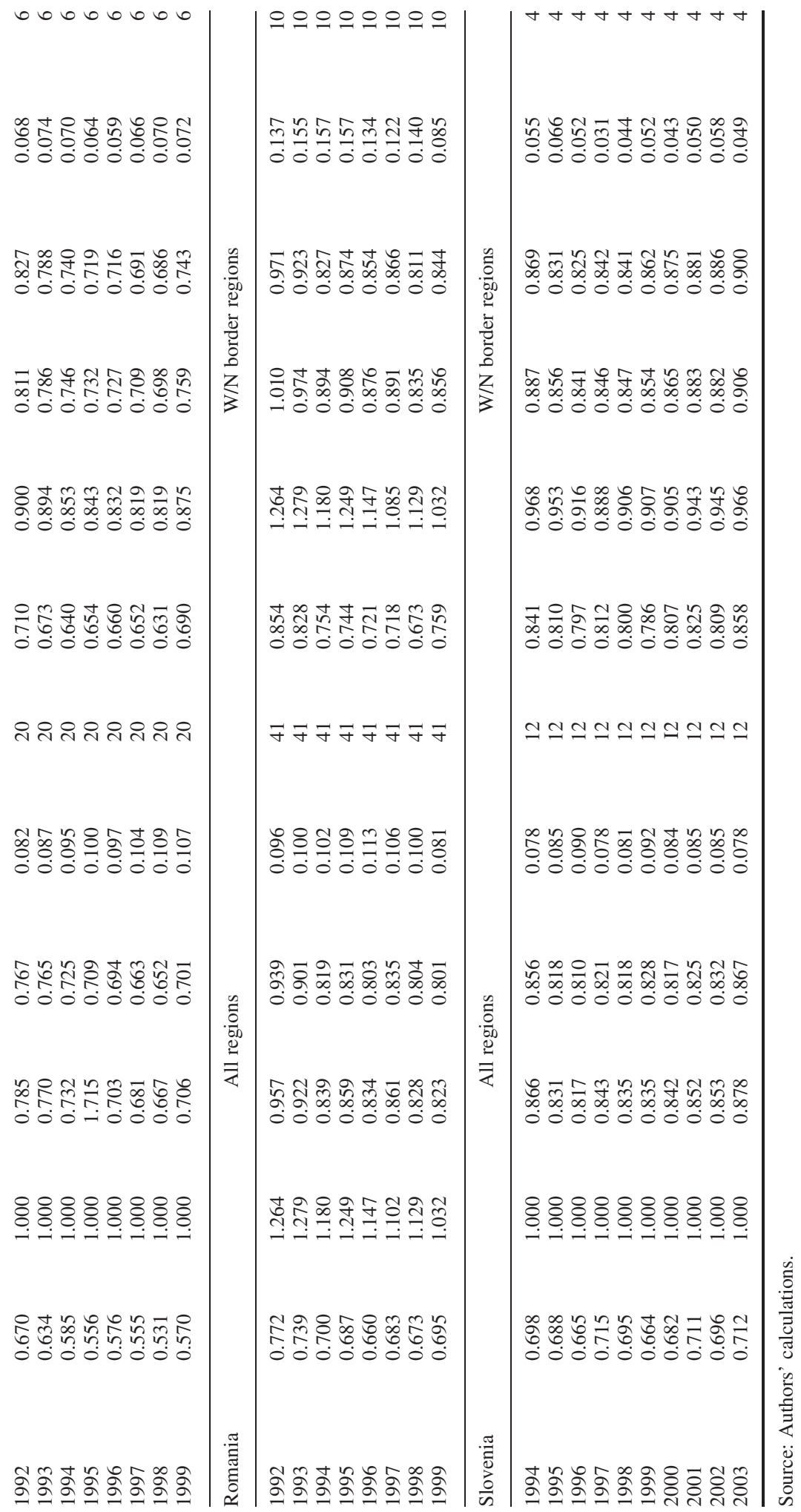




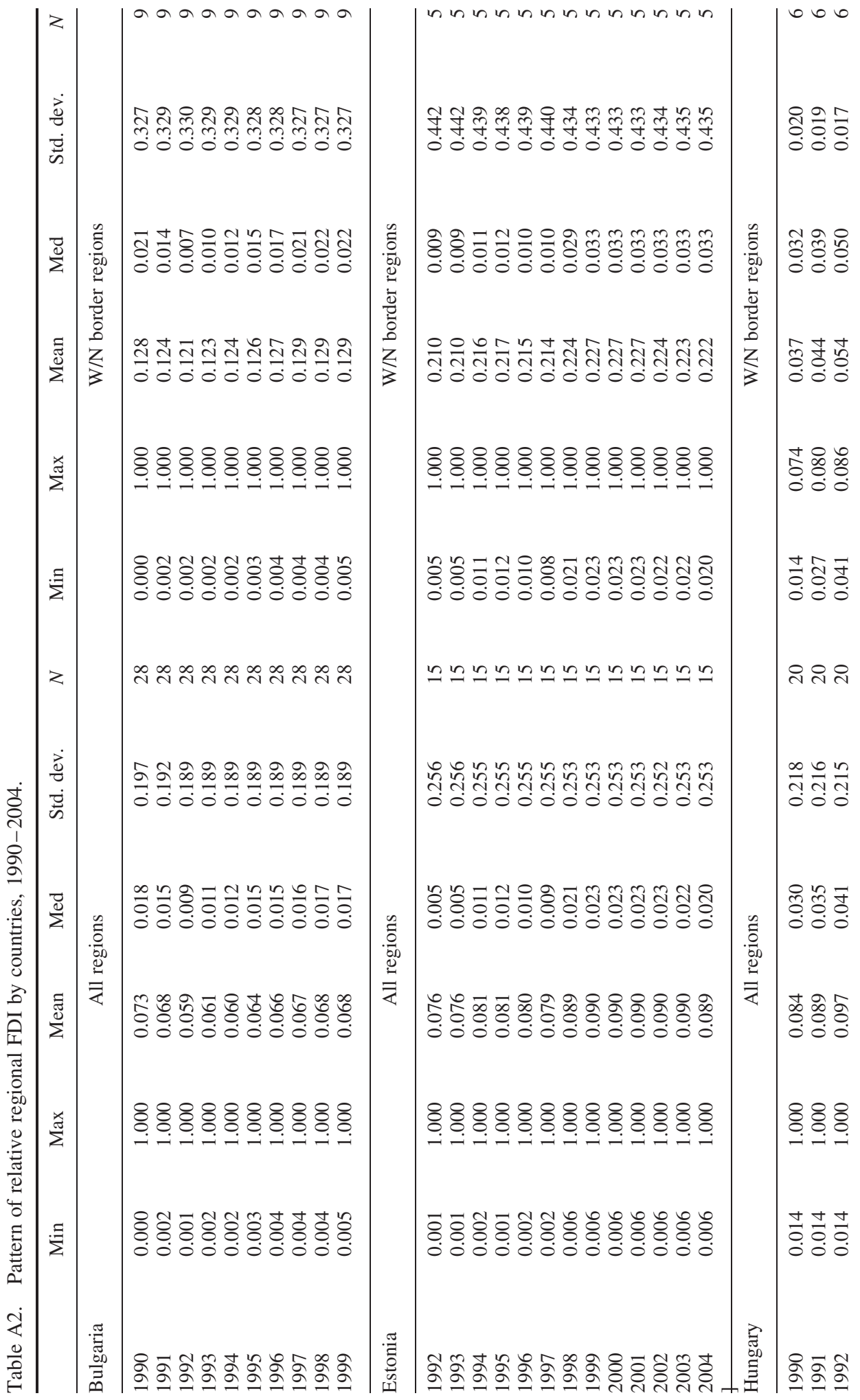




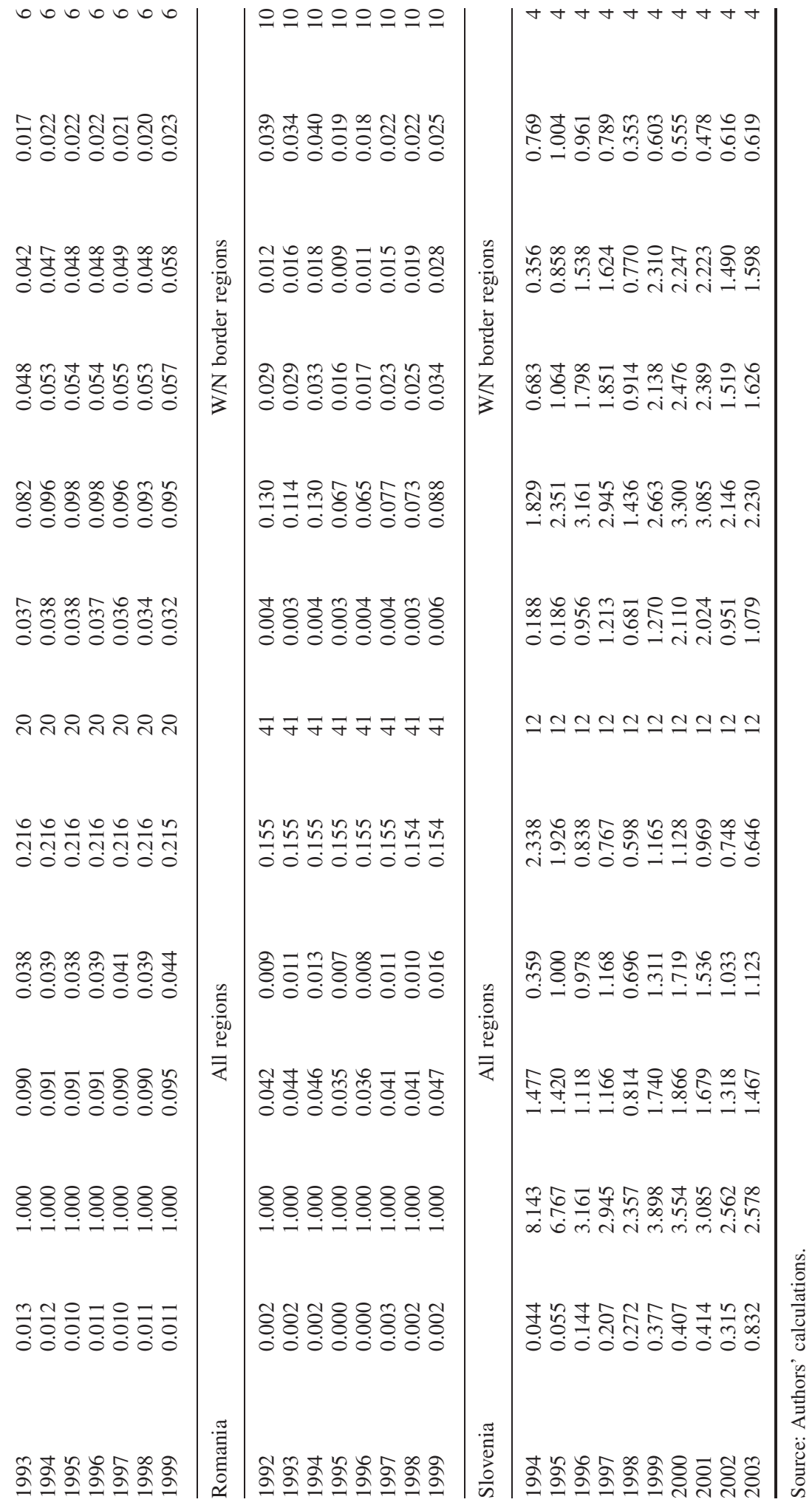

